\title{
Effect of metformin on the expression of SNARE proteins in the skeletal muscle of rats with type 2 diabetes
}

\author{
Yaser Mohammadi ${ }^{1}$, Azam Rezaei Farimani ${ }^{10}{ }^{2 *}$
}

\begin{abstract}
Background and Aims: SNARE proteins are composed of a combination of SNAP-23, Stx-4, and VAMP-2 isoforms that are significantly expressed in skeletal muscle. These proteins control the transport of GLUT4 to the cell membranes. The modifications in the expression of SNARE proteins can cause Type 2 diabetes. The present study aimed to assess the effect of metformin on the expression of these proteins in rats.

Materials and Methods: For the purpose of the study, 40 male Wistar rats were randomly selected. Streptozotocin and Nicotinamide were used for the induction of type 2 diabetes. The animals were assigned to five groups $(\mathrm{n}=8)$, including healthy and diabetic groups as control, as well as three experimental groups which were treated with different doses of metformin $(100,150$, and $200 \mathrm{mg} / \mathrm{kg}$ body weight) for 30 days. The quantitative reverse transcription PCR (RT-qPCR) method was applied to evaluate the expression of SNARE complex proteins.

Results: Based on the results, metformin (100, 150, and $200 \mathrm{mg} / \mathrm{kg}$ body weight) decreased serum glucose levels and increased serum insulin levels. This difference in dose of $200 \mathrm{mg} / \mathrm{kg}$ body weight was statistically significant $(\mathrm{P}<0.05)$. Moreover, all three doses of metformin increased the expression of SNAP- 23, syntaxin-4, and VAMP-2 proteins in skeletal muscle tissue. Metformin at a dose of $200 \mathrm{mg} / \mathrm{kg}$ body weight demonstrated the most significant effects $(\mathrm{P}<0.05)$.

Conclusion: As evidenced by the results of the current study, another anti-diabetic mechanism of metformin is to increase the expression of SNARE proteins, which effectively improves insulin resistance and lowers blood glucose.
\end{abstract}

Keywrods: Diabetic rats, Metformin, SNAP-23, SNARE proteins, Stx-4, Type 2 diabetes, VAMP-2

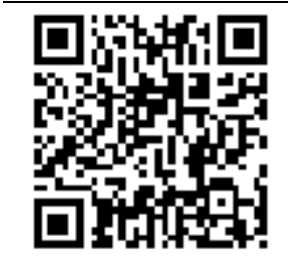

Citation: Mohammadi Y, Rezaei Farimani A. [Effect of metformin on the expression of SNAER proteins in the skeletal muscle of rats with type 2 diabetes]. J Birjand Univ Med Sci. 2021; 28(3): 270-278. [Persian]

DOI http://doi.org/10.32592/JBirjandUnivMedSci.2021.28.3.105

Received: July 10, 2021

Accepted: September 5, 2021

\footnotetext{
${ }^{1}$ Department of Biochemistry, Faculty of Medicine, Birjand University of Medical Sciences, Birjand, Iran

${ }^{2}$ Cardiovascular Diseases Research center, Birjand University of Medical Sciences, Birjand, Iran

* Corresponding author: Cardiovascular Diseases Research center, Birjand University of Medical Sciences, Birjand, Iran

Tel: +989155599058

E-mail: rezaei1@yahoo.com
} 


\title{
اثر متفورمين بر بيان بروتئينهاى SNARE در عضله اسكلتى موشهاى صحرايى مبتلا به ديابت نوع r
}

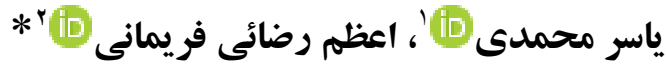

\section{جككيله}

زمينه و هدف: يروتئين هاى SNARE از مجموع ايزوفرمهاى Stx-4 SNAP-23 و

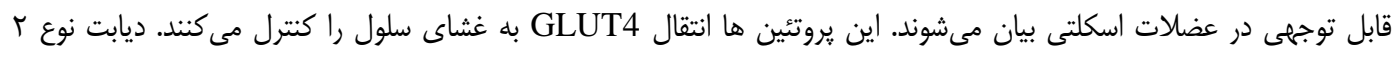

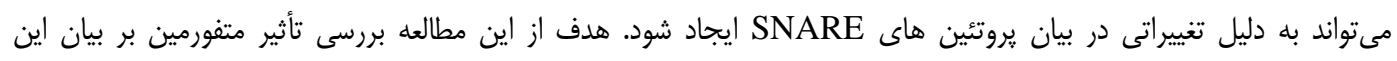
بروتئين ها بود.

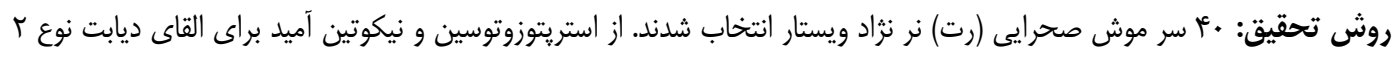

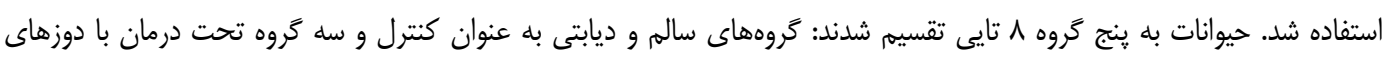

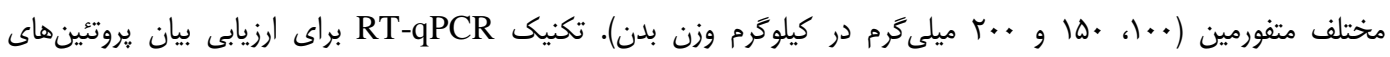
SNARE

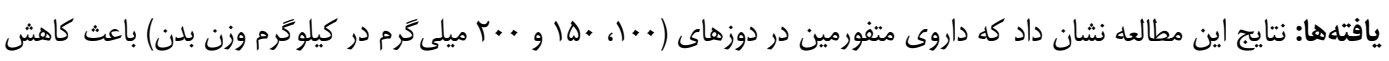

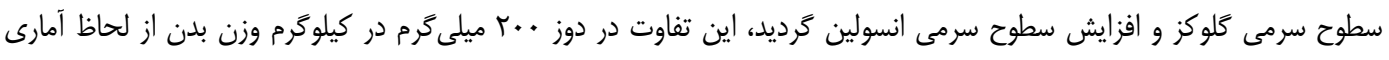

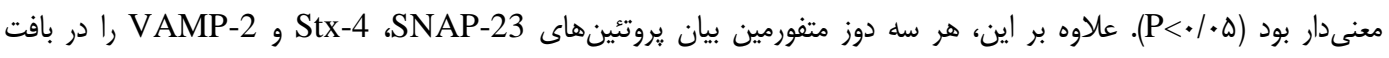

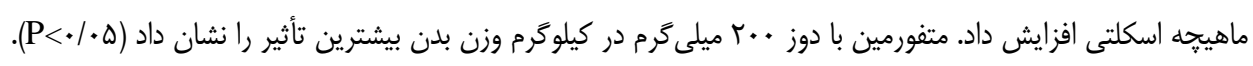

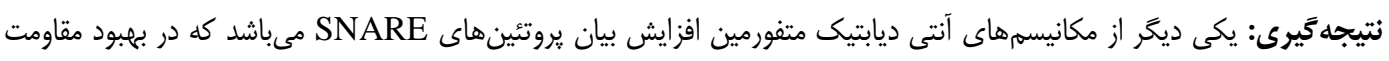
به انسولين و كاهش تلوكز خون مؤثر مىباشئ. وازههاى كليدى: موشهاى صحرايى ديابتى، متفورمين، SNAP-23، يروتئينهاى SNARE، Stx-4 ديابت نوع ז، VAMP-2

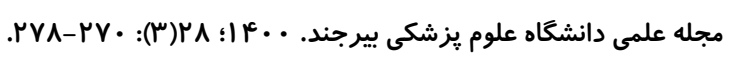

$$
\text { دريافت: }
$$

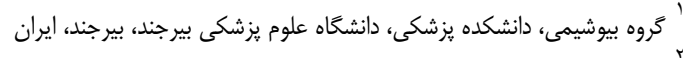

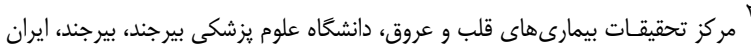

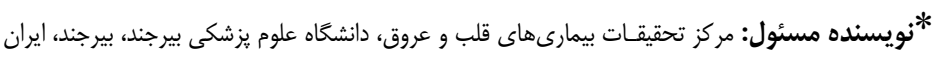

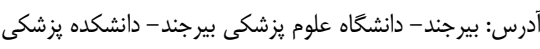

$$
\begin{aligned}
& \text { يست الكترونيكى: azam_rezaei1 @ yahoo.com }
\end{aligned}
$$

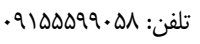


اكزوسيتوز انسولين نيز به دليل كاهش بيان بروتئينهاى SNARE

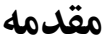
در T2D كاهش مىيابد. بنابراين، طبق شواهد موجود، تغيير در

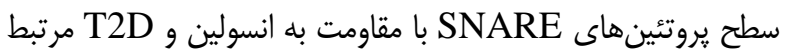

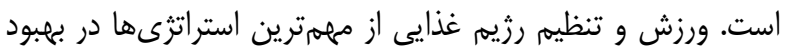

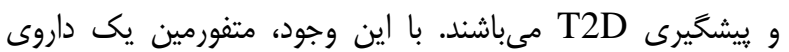

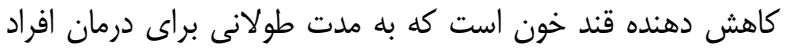
مبتلا به ديابت T2D از آن استفاده شده است. مطالعات نشان داده است كه متفورمين با كاهش توليد كلوكز در كبد، بهبود عملكرد

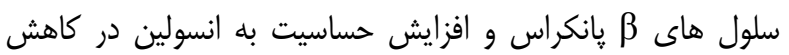

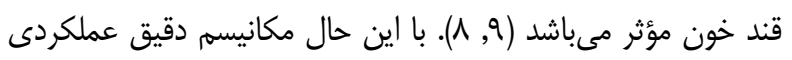

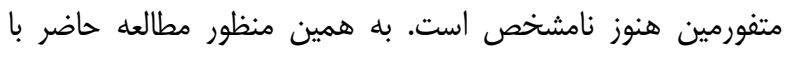

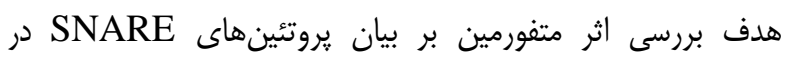

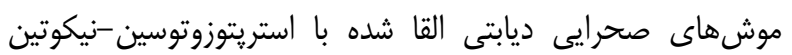

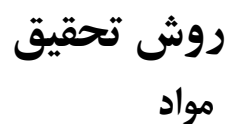

يودر استريتوزوتوسين (STZ) از شركت آمازون ايالت متحده

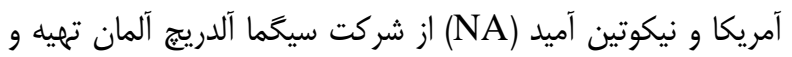
خريدارى شد. كيت الايزا جهت اندازهيرى انسولين از ALPCO، ايالات متحده آمريكا تهيه شد.

\section{طراحى مطالعه حيوانى}

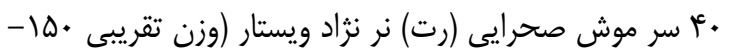

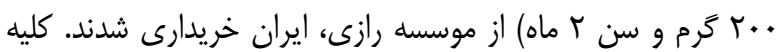

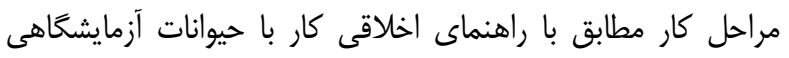

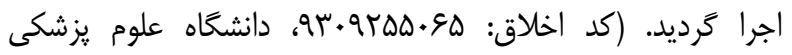
همدان). به منظور سازكًارى با محيط، حيوانات به مدت يكى هفته در

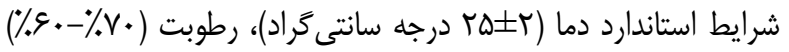

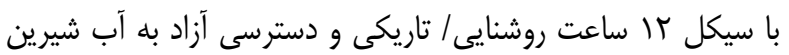
و غذاى يليت شده استاندارد نخكدارى شدند.

ديابت مليتوس يكى از شايعترين انواع اختلالات متابوليك با

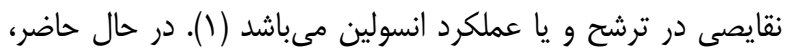
بيش از الها ميليون نفر در سراسر جهان از بيمارى ديابت رنج

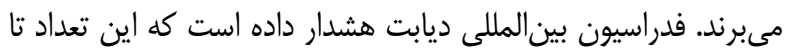

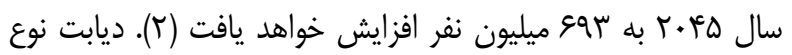

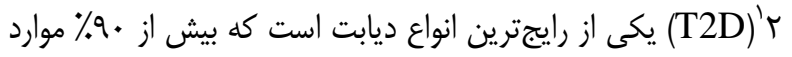
بيمارى را شامل مى شود. علت اصلى اين بيمارى مقاومت به انسولي انسولين

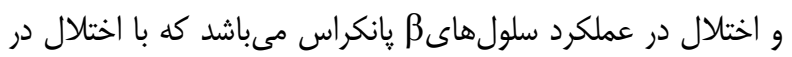

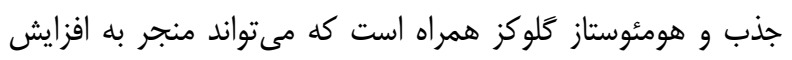

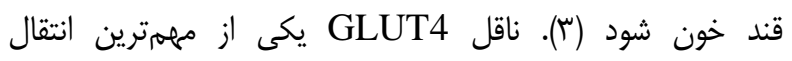
دهندهاى كلوكز است كه وابسته به انسولين بوده و در سلولهاى

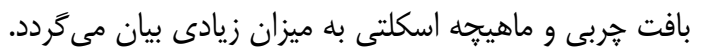

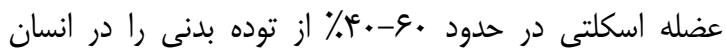
شامل مى گردد و يكى از اصلىترين اركانهاى مصرف كننده كلوكز محسوب مى شود. در نتيجه به عنوان تنظيم كننده اصلى هومئوستاز

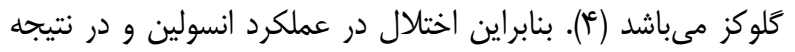

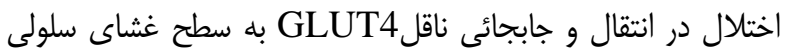
با كاهش برداشت كلوكز از خون توسط سلول هاى عضله اسكلتى و

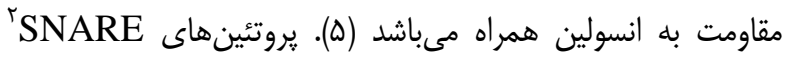

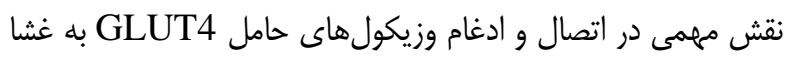
را بر عهده دارند. SNA اجزاى اصلى مجموعه يروتئينى SNARE شناخته مىشوند (ع).

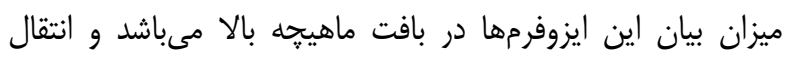

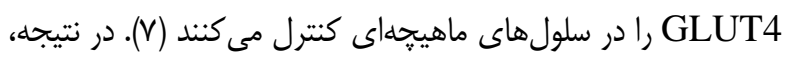

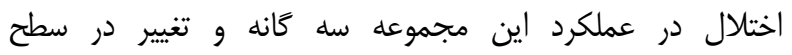

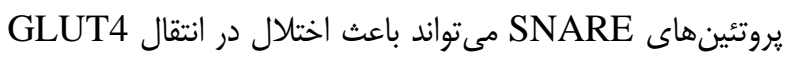

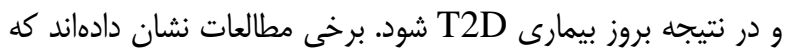

\footnotetext{
${ }^{1}$ Type 2 Diabetes

${ }^{2}$ Soluble N-ethylmaleimide-sensitive factor attachment protein receptor

${ }^{3}$ synaptosomal-associated protein 23

4 syntaxin-4

${ }^{5}$ vesicle-associated membrane protein 2
} 
داده شد. كرايوويالهاى حاوى نمونه بلافاصله در نيتروزن مايع منجمد شده و سيس در دماى •^- درجه سانتى نخحهدارى شدند. نمونههاى خون در لولههاى عارى از ماده ضد انعقاد

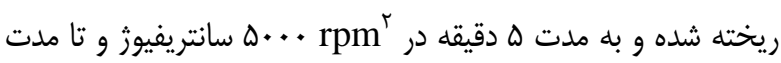

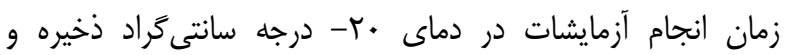
نخمبداى شدند.

\section{RNA استخراج}

استخراج RNA به صورت دستى و با استفاده از معرف ترايزول انجام شد. ...اميلى گرم از هر نمونه بافت فريزشده

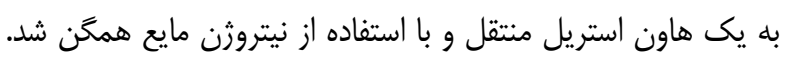
هر نمونه بافت كاملاً هموثن به لولهاى حاوى يكى ميلىليتر ترايزول

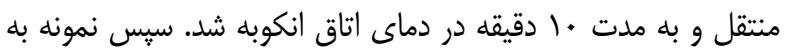

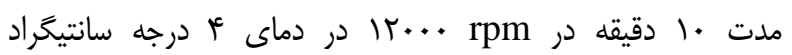
سانتريفيوز و مايع روئى به يك ميكروتيوب منتقل شد. r/ • ميلىليتر

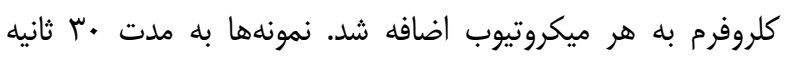
ورتكس و وبه مدت ب-r دقيقه در دماى اتاق انكوبه شدند.

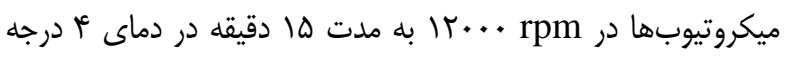
سانتيكراد سانتريفيوز شدند. فاز رويى حاوى RNA با احتياط و بدون بدون

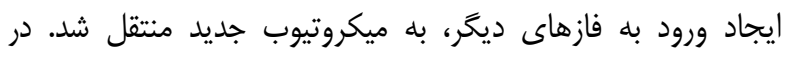
مرحله بعدى، رسوب دهى RNA با حجم مساوى ايزويرويانول

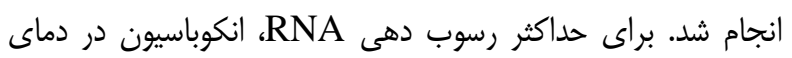

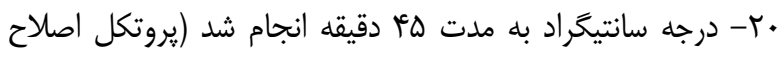

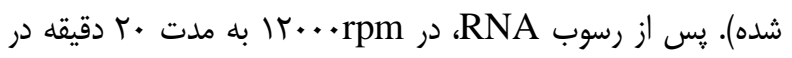

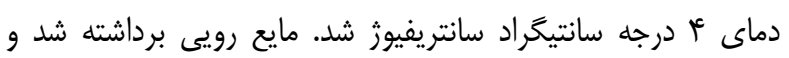

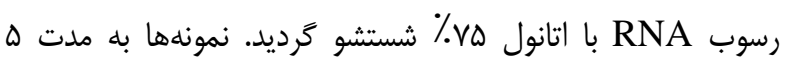

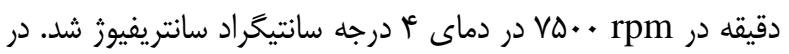

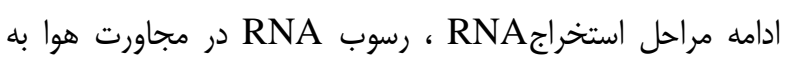
مدت ه-•1 دقيقه خشك شد و در نهايت با هند بند بار عمليات

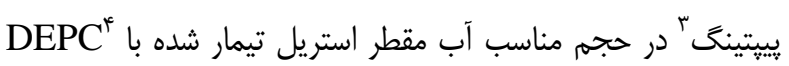

\footnotetext{
${ }^{2}$ Revolutions per minute

${ }^{3}$ Pipetting

${ }^{4}$ Diethyl pyrocarbonate
}

القا ديابت و گَروه بندى

جهت القاى ديابت T2D در موشهاى صحرايى، با رعايت

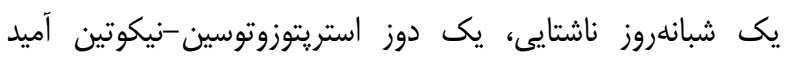

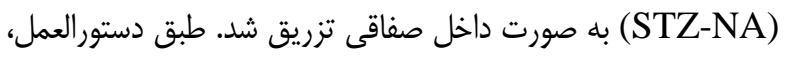

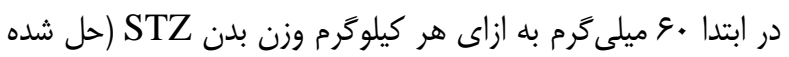

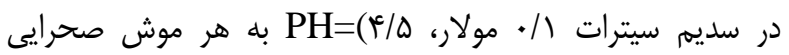

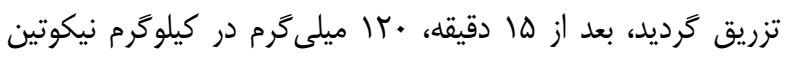

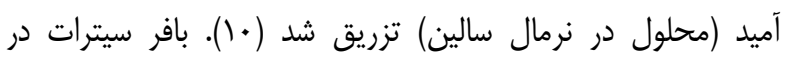

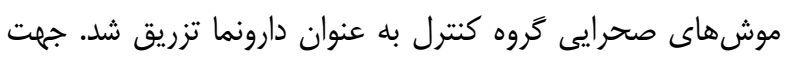

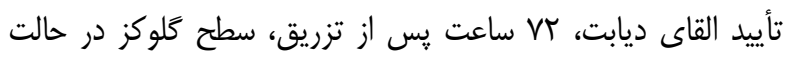
ناشتا با استفاده از يك دستخاه كلوكومتر مدل Accu Chek (Roche)

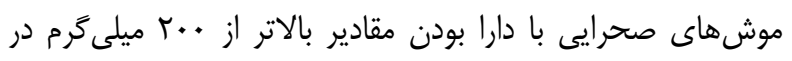

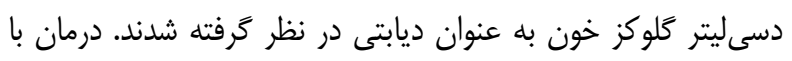

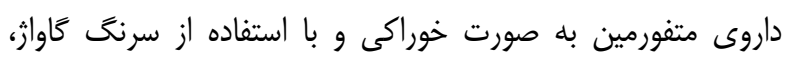

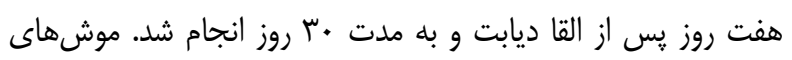

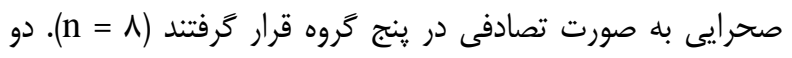

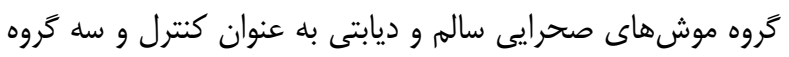
موشهاى صحرايى ديابتى تحت درمان با دوزهاى مختلف متفورمين

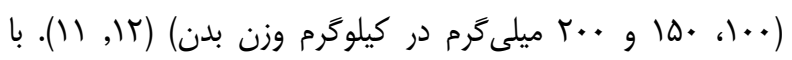
توجه به بيش بينى احتمال مرى و مير موش هاى صحر ائى بدنبال

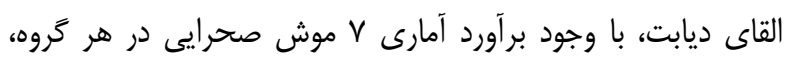

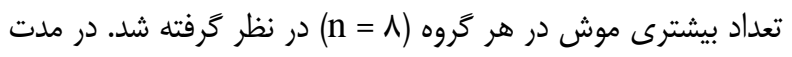
زمان مطالعه يك موش صحرايى در گروه كنترل ديابتى از بين رفت.

\section{نمونه كيرى}

يس از اتمام دوره مداخله، موشهاى صحرايى با تزريق داخل

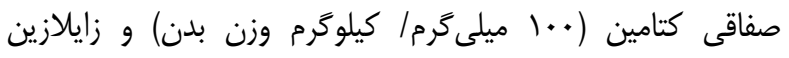

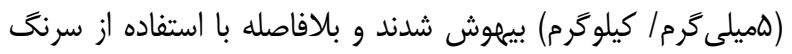
•1 سى سى، از وريد اجوف تحتانى خونيَى انجام شد. بافت

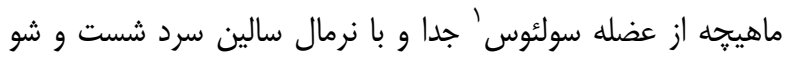

${ }^{1}$ Soleus muscle 
Bio-Rad, ) CFX96 real-time PCR سه بار تكرار در دستخاه ) و طبق برنامه زير انجام شد: يك سيكل در دماى هو درجه دئهاه

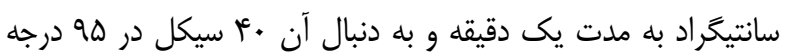

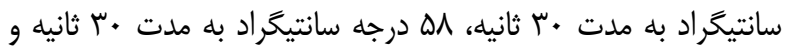

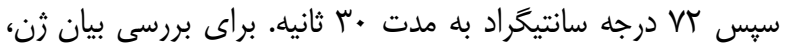

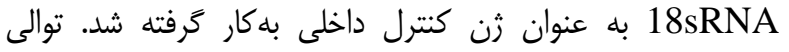

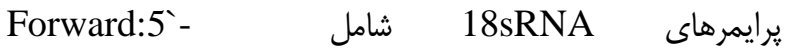
Reverse: 5 - و dGTAACCCGTTGAACCCCATT dCCATCCAATCGGTAGTAGCG يرايمرهاى مربوط به زن هاى مورد نظر در جدول آ آورده شده است.

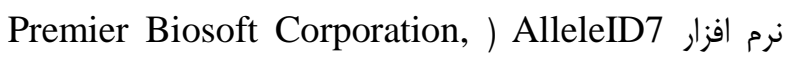
(USA براى طراحى يرايمرهاى اختصاصى هر زن استفاده شد.
حل و براى استفاده طولانى مدت به فريزر •م -درجه سانتيخراد

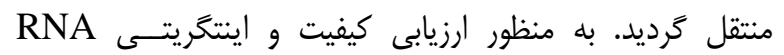

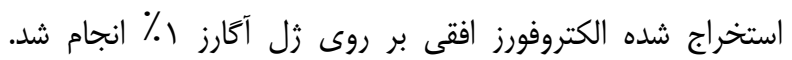

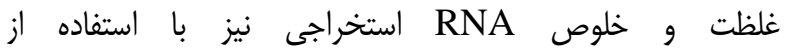

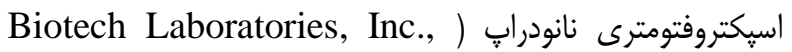
(USA ) انجام شد.

\section{سنتز cDNA و انجام واكنثشهاى Real-Time PCR} Fermentas, ) cDNA با استفاده از كيت سنتز (Burlington, ON, Canada دستورالعمل سازنده، رونويسى شد. واكنشهاى qPCR-RT با باى

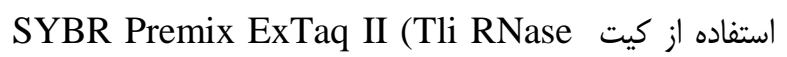
انجام شد. واكنش براى هر نمونه با (Takara, China) HPlus)

جدول ا - توالى يرايمرها در واكنش Real-Time PCR

\begin{tabular}{lccc}
\hline & SNAP-23 & Syntaxin-4 & VAMP-2 \\
\hline $\begin{array}{l}\text { NCBI accession } \\
\text { number }\end{array}$ & NM_022689.2 & NM_031125.1 & NM_012663.2 \\
$\begin{array}{l}\text { Sequence (5'->3') } \\
\text { Forward primer }\end{array}$ & TTCCGTTTCTGTGTCCAATAG & TCAGCAGACTATGTGGAAC & CTACTTGGTCCTAAGAATCC \\
Reverse primer & TTGTGCTTTCCAGAGACTCAT & CCAAGATGAGAACAGTGACA & CAGAAGAGTGAAGAGTAATGG \\
\hline
\end{tabular}

\section{يافته ها}

اثر متفورمين بر سطوح سرمى تَلوكز، انسولين و اندكس HOMA-IR'

نتايج اين مطالعه نشان داد كه سطح سرمى گلوكز در گروه كنترل ديابتى در مقايسه با كروه كنترل سالم بيشتر بود، اين اختلاف

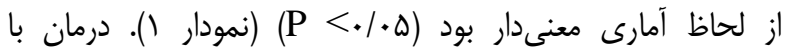
دوزهاى مختلف متفورمين سطح سرمى، گلوكز را در مقايسه با كروه كنترل ديابتى كاهش داد، به طورى كه سطح سرمى كلوكز در

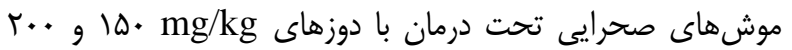
متفورمين در مقايسه با موشهاى صحرايى ديابتى گروه كنترل

\footnotetext{
${ }^{1}$ Homeostatic model assessment (HOMA) (insulin resistance index)
}

تجزيه و تحليل آمارى

نتايج به صورت ميانخين لانحراف معيار بيان شدهاند. تفاوت آمارى در مطالعه يارامترها در بين گروهها با استفاده از نرم افزار

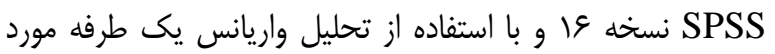

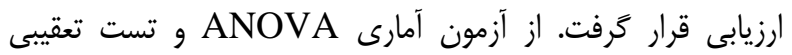
توكى (Turkey’s test) براى ارزيابى تفاوت ميانكَين دادهها بين كروههاى مورد مطالعه استفاده شد. در تمام مراحل تجزيه و تحليل

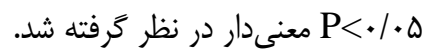




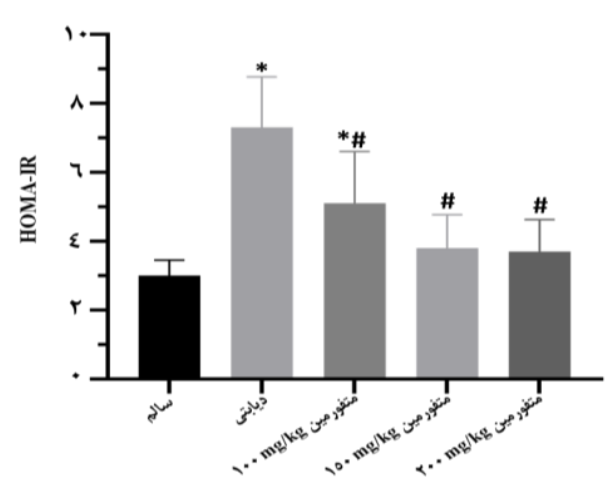

نمودار - "ّ: ميانكَين اندكس HOMA-IR به تفكيك كروههاى مورد مطالعه

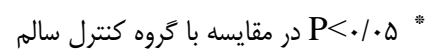

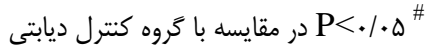

اثر متفور مين بر بيان ثنهاى Syntaxin-4 SNAP-23 و دافت VAMP-2

مقايسه ميانگَينهاى $\Delta \mathrm{Ct}$ بين گروههاى مورد مطالعه در جدول ب گزارش شده است. نتايج مطالعه نشان داد كه ميانگين

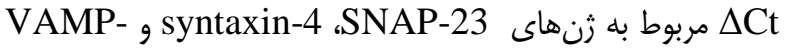
2 در گروههاى ديابتى و تحت درمان با دوزهاى مختلف متفورمين

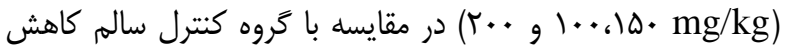
داشت كه اين نشان دهنده افزايش بيان هر سه ثن در اين گروهها

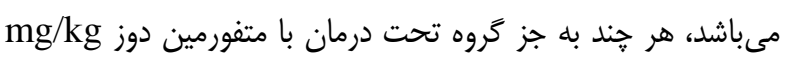

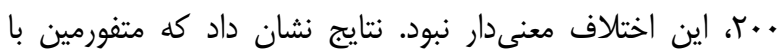

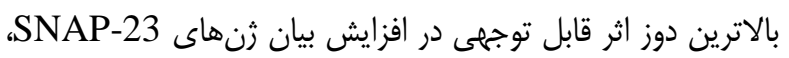
VAMP-2 و Stx-4
كاهش معنى دارى داشت (ه•/P<). سطوح سرمى انسولين به طور معنى دارى در گروه تحت درمان با بالاترين دوز متفورمين

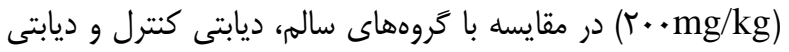
تحت درمان با دوز مقادير اندكس HOMA-IR نشان داد كه اين اندكس بالاترين ميزان را در گروه ديابتى كنترل نسبت به ساير گروهها دارد

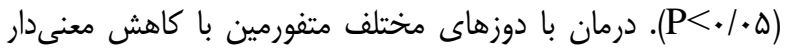

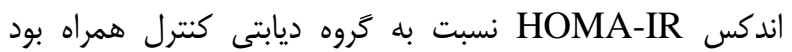

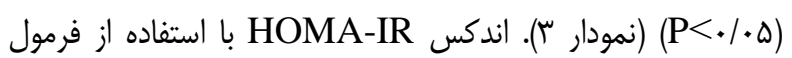

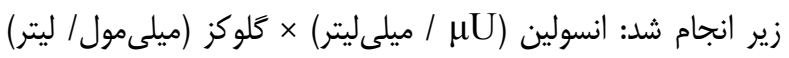

. (IT) T/D/

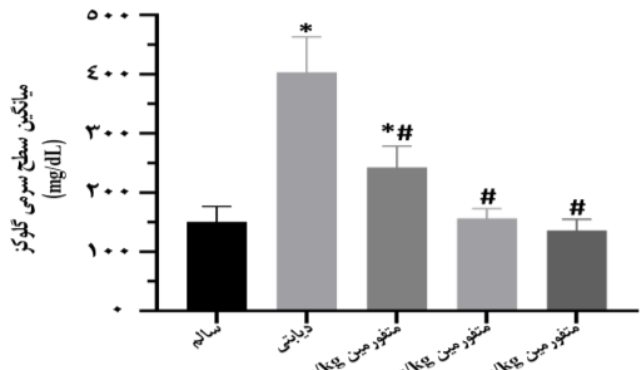

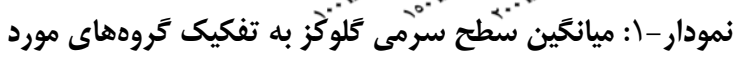
مطالعه

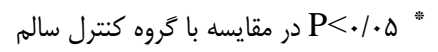

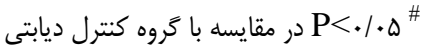

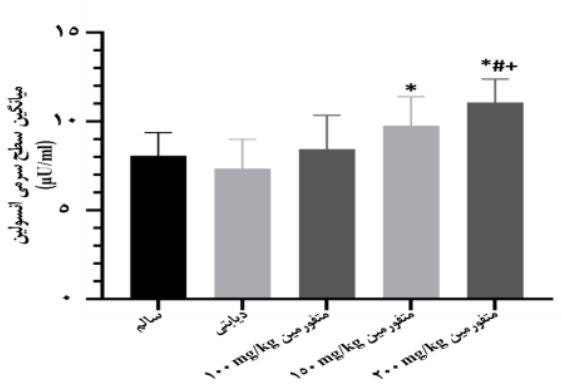

نمودار --ז: ميانَين سطح سرمى انسولين به تفكيك كَروهاى مورد مطالعه

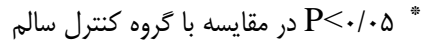

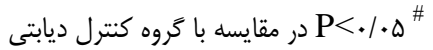

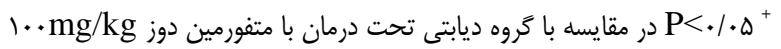


جدول r - مقايسه ميانكَين DCt مربوط به زن هاى Stx-4 SNAP-23 و VAMP-2 در تروههاى مورد مطالعه

\begin{tabular}{|c|c|c|c|c|c|}
\hline ديابتى+متفور مين & ديابتى+متفور مين & ديابتى+متفورمين & ديابتى & سالم & كروهها \\
\hline$r++\mathrm{mg} / \mathrm{kg}$ & $10+\mathrm{mg} / \mathrm{kg}$ & $1++\mathrm{mg} / \mathrm{kg}$ & & & \\
\hline$\varphi / V V \pm 1 / \cdot 1^{a}$ & $9 / \cdot 1 \pm \cdot / / \mathrm{V}$ & $V / \sim \mu \pm \cdot / 1$ & $V / \mathscr{e} \nabla \pm 1 / r r$ & $1 \cdot 1 \cdot 1 \pm \cdot / 8$ & SNAP-23 \\
\hline$\Delta / \Delta \sim \pm \cdot / \Delta \Delta^{\mathrm{a}}$ & $s / V V \pm 1 / \cdot V$ & $N / \varphi \& \pm \cdot / \mu \psi$ & G/VDA. $/ 9 \mathrm{~V}$ & $q / 94 \pm 1 / / f$ & Stx-4 \\
\hline$\varepsilon / \Delta \mid \pm \cdot / \varepsilon \Delta^{\mathrm{a}}$ & $q / q \gamma \pm \cdot / r v$ & N/זீ $\Delta \pm \cdot / q \mu$ & $q / / \Delta \pm \cdot / V r$ & $9 / \wedge \uparrow \pm . / 91$ & VAMP-2 \\
\hline
\end{tabular}

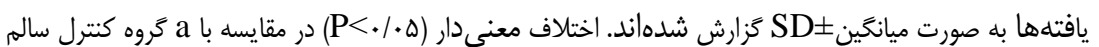

حال، مكانيسم اين اثر تا حد زيادى ناشناخته است.

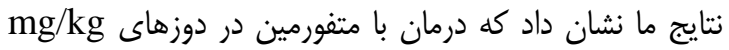

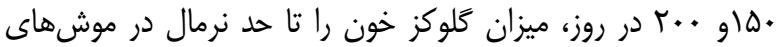
mg/kg صحرايى ديابتى كاهش داد؛ اما درمان يك ماهه با دوز

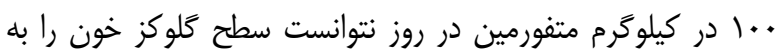

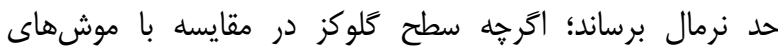

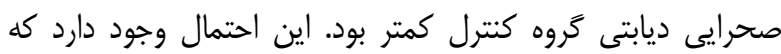
يكى از مكانيسمهاى متفورمين در كاهش كلوكز خون افزايش توليد و ترشح انسولين مىباشد؛ به طورى كه سطوح بالاتر انسولين در سرم موشهاى صحر ايى ديابتى تحت درمان با متفورمين با دوزهاى

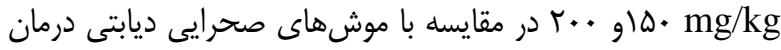
نشده مشاهده كرديد. با اين حال، برخى از مطالعات قبلى نشان دادهاند كه متفورمين تأثير بيشترى در افزايش حساسيت به انسولين دارد (^, 9). مشابه با جنين مطالعاتى نتايج حاصل از اين مطالعه نشان داد كه متفورمين باعث كاهش مقاومت به انسولين مى

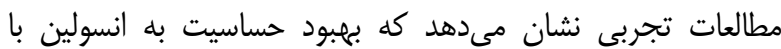
واسطه متفورمين ممكن است با مكانيسمهاى مختلفى همراه باشد،

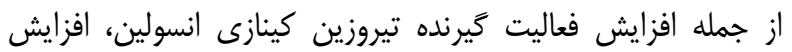

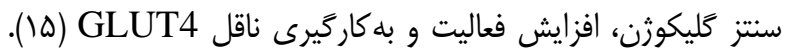
مطالعات نشان داده است كه درمان با متفورمين با كاهش اندوسيتوز

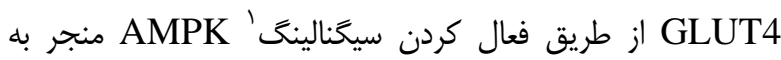

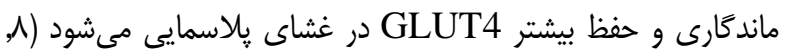

\footnotetext{
${ }^{1}$ AMP-activated protein kinase
}

از آنجايى كه اختلال در ترشح انسولين و مقاومت به انسولين دو علت اصلى T2D هستند، شناسايى مكانيسمهاى مؤثر مولكولى درگير، براى ييشخيرى و درمان T2D ضرورى مىباشد. ناقل

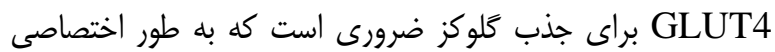
در دو بافت حساس به انسولين يعنى بافت جربى و عضله اسكلتى

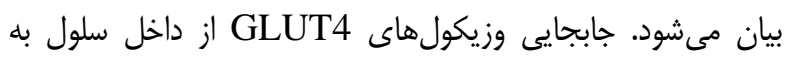

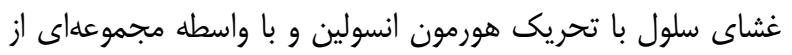
يروتئينها تحت عنوان SNAREs صورت مى مئيرد. در ميان

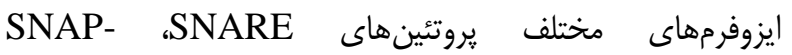

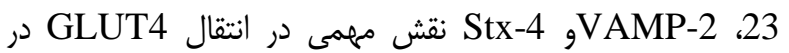
بافت ماهيحه به عهده دارند. بر اساس مطالعات انجام شده، اختالال در انتقال GLUT4 با واسطه يروتئينهاى SNARE منجر به ايجاد مقاومت به انسولين و در نتيجه افزايش كلوكز خون مىشود

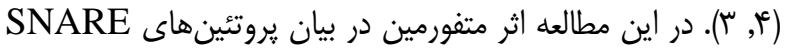

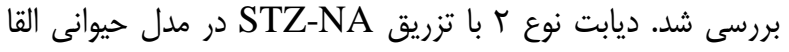
شد كه تا حدودى مشابه به ديابت نوع r در انسان مى باشد. نيكوتين

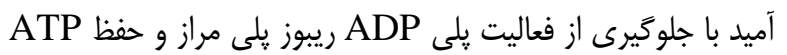

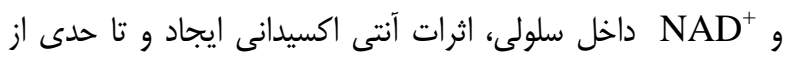

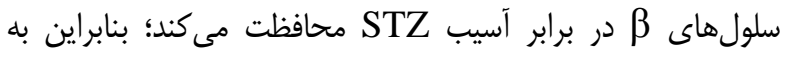
عنوان يك رويكرد مناسب در القاى مدلى براى T2D در نظر كرفته

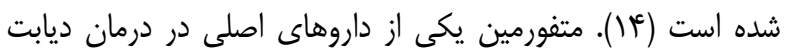
است كه به صورت خوراكى مصرف مى گردد. مطالعات نشان داده

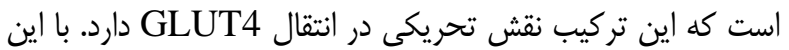


SNARE دمى T2D مياشد. نتايج حاصل از اين مطالعه نشان داد

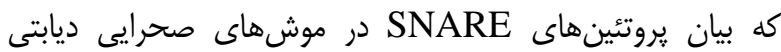
تحت درمان با متفورمين افزايش يافت. متفورمين با بالاترين دوز

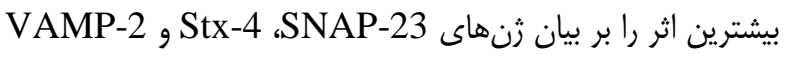

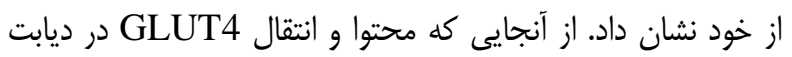

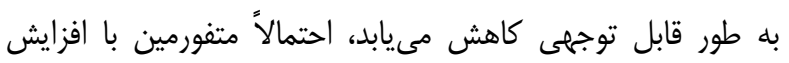
بيان يروتئينهاى SNARE در صدد جبران اين اختلال مى باشد.

\section{نتيجه Fيرى}

يكى ديكر از مكانيسمهاى آنتى ديابتيك متفورمين افزايش

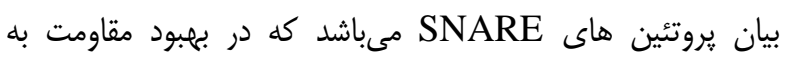
انسولين و كاهش كلوكز خون مؤثر مىباشد.

\section{تقدير و تشكّر}

نويسندكان از دانشخاه علوم يزشكى همدان به دليل فراهم

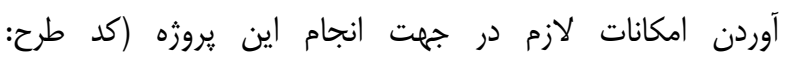

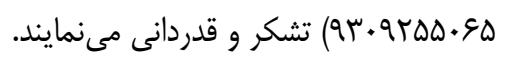

تضاد منافع

نويسندكان مقاله اعلام مى دارند كه هيج كَونه تضاد منافعى در

$$
\text { مطالعه حاضر وجود ندارد. }
$$

برخى مطالعات ارتباط بين اختلال در بيان يروتئينهاى

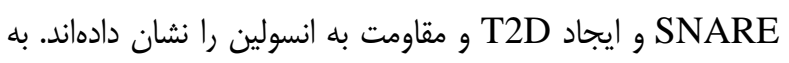
طورى كه مشخص كرديده است بيان برخى از ايزوفرمهاى يروتئين

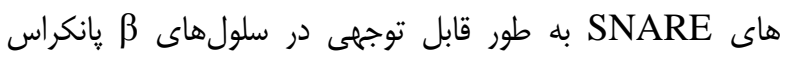
كاهش يافته است (VIV, IV). در مقابل، مطالعاتى نشان دادهاند كه بيان يروتئين هاى SNARE در عضلات اسكلتى تحت شرايط

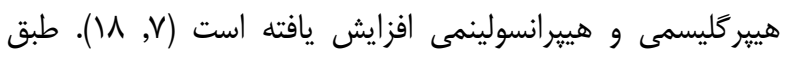
مطالعات انجام شده، ميزان GLUT4 و سطح انسولين از عوامل

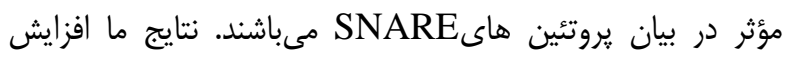

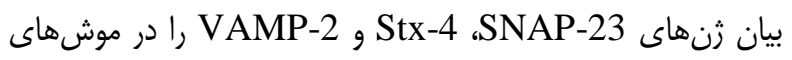
صحرايى ديابتى نسبت به گروه كنترل سالم نشان داد؛ هر جند اين

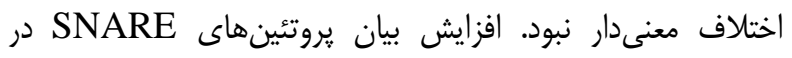

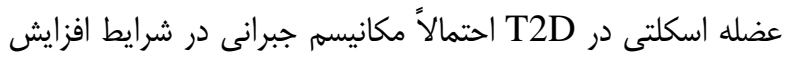

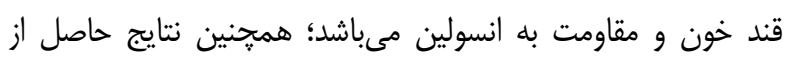

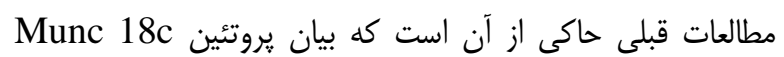

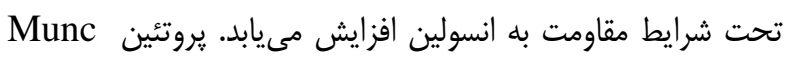
18c يك عامل تنظيم كننده براى بروتئينهاى SNARE

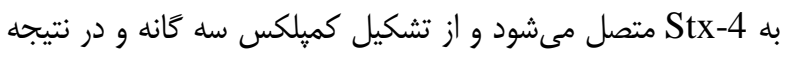

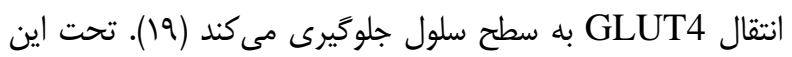

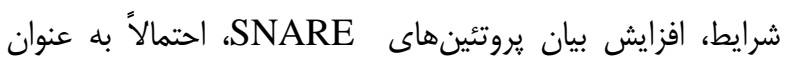

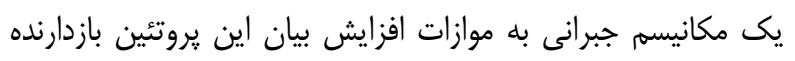

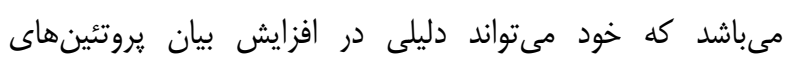

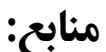

1- Chellappan DK, Yap WS, NA BAS, Gupta G, Dua K. Current therapies and targets for type 2 diabetes mellitus. Panminerva Med. 2018; 60(3): 117-31. DOI: 10.23736/s0031-0808.18.03455-9

2- Cho N, Shaw J, Karuranga S, Huang Yd, da Rocha Fernandes J, Ohlrogge A, et al. IDF Diabetes Atlas: Global estimates of diabetes prevalence for 2017 and projections for 2045. Diabetes Res Clin Pract. 2018; 138: 271-81. DOI: $10.1016 /$ j.diabres.2018.02.023

3- Zhou T-T, Ma F, Shi X-F, Xu X, Du T, Guo X-D, et al. DMT efficiently inhibits hepatic gluconeogenesis by regulating the Gaq signaling pathway. J Mol Endocrinol. 2017; 59(2): 151-69. DOI: 10.1530/JME-17-0121

4- Lauritzen HP, Schertzer JD. Measuring GLUT4 translocation in mature muscle fibers. Am. J. Physiol. Endocrinol. Metab. AM J PHYSIOL-ENDOC M. 2010;299(2):E169-E79. DOI: 10.1152/ajpendo.00066.2010

5- Stöckli J, Fazakerley DJ, James DE. GLUT4 exocytosis. J Cell Sci. 2011; 124(24): 4147-59. DOI: $10.1242 /$ jcs.097063 
6- Mohseni R, ArabSadeghabadi Z, Ziamajidi N, Abbasalipourkabir R, RezaeiFarimani A. Oral administration of resveratrol-loaded solid lipid nanoparticle improves insulin resistance through targeting expression of SNARE proteins in adipose and muscle tissue in rats with type 2 diabetes. Nanoscale Res Lett. 2019; 14(1): 227. DOI: 10.1186/s11671-019-3042-7.

7- Farimani AR, Goodarzi MT, Saidijam M, Yadegarazari R, Zarei S, Asadi S. Effect of resveratrol on SNARE proteins expression and insulin resistance in skeletal muscle of diabetic rats. Iran J Basic Med Sci. 2019; 22(12): 1408-14. DOI: 10.22038/IJBMS.2019.13988

8- Viollet B, Guigas B, Garcia NS, Leclerc J, Foretz M, Andreelli F. Cellular and molecular mechanisms of metformin: an overview. Clin Sci (Lond). 2012; 122(6): 253-70. DOI: 10.1042/CS20110386

9- Yang X, Xu Z, Zhang C, Cai Z, Zhang J. Metformin, beyond an insulin sensitizer, targeting heart and pancreatic $\beta$ cells. Biochim Biophys Acta Mol Basis Dis. 2017; 1863(8): 1984-90. DOI: 10.1016/j.bbadis.2016.09.019

10- Sheela N, Jose MA, Sathyamurthy D, Kumar BN. Effect of Silymarin on Streptozotocin-Nicotinamide--induced Type 2 Diabetic Nephropathy in Rats. Iran J Kidney Dis. 2013; 7(2):117-23. DOI: 10.1002/jps.20744

11- Choi YH, Kim SG, Lee MG. Dose-independent pharmacokinetics of metformin in rats: Hepatic and gastrointestinal first-pass effects. J. Pharm. Sci. 2006; 95(11):2543-52. DOI: 10.1002/jps.20744

12- Zhai L, Gu J, Yang D, Wang W, Ye S. Metformin ameliorates podocyte damage by restoring renal tissue podocalyxin expression in type 2 diabetic rats. J. Diabetes Res. 2015; 2015. DOI: 10.1155/2015/231825

13- Katsuki A, Sumida Y, Gabazza EC, Murashima S, Furuta M, Araki-Sasaki R, et al. Homeostasis model assessment is a reliable indicator of insulin resistance during follow-up of patients with type 2 diabetes. Diabetes care. 2001; 24(2): 362-5. DOI: $10.2337 /$ diacare.24.2.362

14- Ghasemi A, Khalifi S, Jedi S. Streptozotocin-nicotinamide-induced rat model of type 2 diabetes. Acta Physiologica Hungarica. 2014;101(4):408-20 .DOI: 10.1556/APhysiol.101.2014.4.2

15- Giannarelli R, Aragona M ,Coppelli A, Del Prato S. Reducing insulin resistance with metformin: the evidence today. Diabetes Metab. 2003; 29(4): 6S28-6S35. DOI: 10.1016/S1262-3636(03)72785-2

16- Maier VH, Melvin DR, Lister CA, Chapman H, Gould GW, Murphy GJ. v-and t-SNARE protein expression in models of insulin resistance: normalization of glycemia by rosiglitazone treatment corrects overexpression of cellubrevin, vesicle-associated membrane protein-2, and syntaxin 4 in skeletal muscle of Zucker diabetic fatty rats. Diabetes. 2000; 49(4): 618-25. DOI: 10.2337/diabetes.49.4.618

17- Abbasi Oshaghi E, Goodarzi MT, Higgins V, Adeli K. Role of resveratrol in the management of insulin resistance and related conditions: Mechanism of action. Crit Rev Clin Lab Sci. 2017; 54(4): 267-93. DOI: 10.1080/10408363.2017.1343274

18- Boström P, Andersson L, Vind B, Håversen L, Rutberg M, Wickström Y, et al. The SNARE protein SNAP23 and the SNARE-interacting protein Munc18c in human skeletal muscle are implicated in insulin resistance/type 2 diabetes. Diabetes. 2010; 59(8): 1870-8. DOI: 10.2337/db09-1503

19- Schlaepfer IR, Pulawa LK, Ferreira LDC, James DE, Capell WH, Eckel RH. Increased expression of the SNARE accessory protein Munc18c in lipid-mediated insulin resistance. J Lipid Res. 2003; 44(6): 1174-81. DOI: 10.1194/jlr.M300003-JLR200 